\title{
POLG Gene
}

National Cancer Institute

\section{Source}

National Cancer Institute. POLG Gene. NCI Thesaurus. Code C143069.

This gene plays a role in the replication of mitochondrial DNA. 